\title{
Active tectonics on Deception Island (West-Antarctica): A new approach by using the fractal anisotropy of lineaments, fault slip measurements and the caldera collapse shape
}

\author{
R. Pérez-López, ${ }^{1}$ J. L. Giner-Robles, ${ }^{1}$ J. J. Martínez-Díaz, ${ }^{2}$ M. A. Rodríguez-Pascua, ${ }^{1}$ M. Bejar, ${ }^{2}$ C. Paredes, ${ }^{3}$ \\ and J. M. González-Casado ${ }^{4}$ \\ ${ }^{1}$ Dpto. de Ciencias Ambientales y Recursos Naturales. Facultad de Farmacia. Universidad San Pablo. Campus Montepríncipe, Boadilla del Monte. \\ Madrid 28668. Spain (rperez.fcex@ceu.es; marodpas@ceu.es; jlginer@ceu.es) \\ ${ }^{2}$ Dpto. Geodinámica. F. CC Geológicas. Universidad Complutense de Madrid. Spain (jmdiaz@geo.ucm.es; martabejar@geo.ucm.es) \\ ${ }^{3}$ Dpto. de Matemática Aplicada y Métodos Informáticos. E.T.S.I.M. Universidad Politécnica de Madrid, Spain (cparedes@dmami.upm.es) \\ ${ }^{4}$ Dpto. de Geología y Geoquímica. Facultad de Ciencias. Universidad Autónoma de Madrid. Spain. (g.casado@uam.es)
}

\begin{abstract}
The tectonic field on Deception Island (South Shetlands, West Antarctica) is determined from structural and fractal analyses. Three different analyses are applied to the study of the strain and stress fields in the area: (1) field measurements of faults (strain analysis), (2) fractal geometry of the spatial distribution of lineaments and (3) the caldera shape (stress analyses). In this work, the identified strain field is extensional with the maximum horizontal shortening trending NE-SW and NW-SE. The fractal technique applied to the spatial distribution of lineaments indicates a stress field with $\mathrm{S}_{\mathrm{HмAX}}$ oriented NE-SW. The elliptical caldera of Deception Island, determined from field mapping, satellite imagery, vents and fissure eruptions, has an elongate shape and a stress field with $\mathrm{S}_{\mathrm{HMAX}}$ trending NE-SW.
\end{abstract}

Citation: Pérez-López, R., J. L. Giner-Robles, J. J. Martínez-Díaz, M. A. Rodríguez-Pascua, M. Bejar, C. Paredes, and J. M. González-Casado (2007), Active tectonics on Deception Island (West-Antarctica): A new approach by using the fractal anisotropy of lineaments, fault slip measurements and the caldera collapse shape, in Antarctica: A Keystone in a Changing World - Online Proceedings of the $10^{\text {th }}$ ISAES, edited by A.K. Cooper and C.R. Raymond et al., USGS Open-File Report 2007-1047, Short Research Paper 086, 4 p.; doi:10.3133/of2007-1047.srp086

\section{Introduction}

Deception Island (South Shetlands, West-Antarctica), is a horseshoe-shaped volcanic island with a welldeveloped collapsed caldera (Port Foster) (Figs. 1, 2). This island lies within a back-arc basin (Galindo-Zaldívar et al., 1996; Gonzalez-Casado et al., 2000) called the Bransfield Strait. The strait is elongated NE-SW and is bounded by a ridge to the southeast and a former trench to the northwest. The area lies in a strike-slip stress regime (Gonzalez-Casado et al., 1999) with $\mathrm{S}_{\mathrm{H} \max }$ (maximum horizontal stress) trending NE-SW and $\mathrm{S}_{\mathrm{Hmin}}$ (minimum horizontal stress) trending NW-SE. The Island evolved from submarine pillow lavas to subaerial eruptions, mainly strombolian and phreatomagmatic.

Several structural analyses of the Bransfield Strait and Deception Island using fault population analysis, seismotectonics of focal mechanism solutions, tectonic geomorphology, etc. (e.g., Rey et al., 1995; Smellie, 2002; González-Casado et al., 1999, 2000; FernándezIbáñez et al., 2005; Maestro et al., 2007; amongst others), propose two tectonic models: (1) A complex Riedel model under strike-slip stress regime (Maestro et al., 2007), (2) lithospheric thinning within an extensional strain regime with left-lateral component (ey NE-SW) and uniaxial extension probably related with the caldera collapse (ey NW-SE trending) (Pérez-López et al., 2006, Paredes et al., 2006).

The main problem for stress and strain microanalyses on Deception Island is that tectonic indicators are scarce in volcanic rocks.

Nevertheless, the tectonic field can be established from fault slip sense measurements and dike trending.

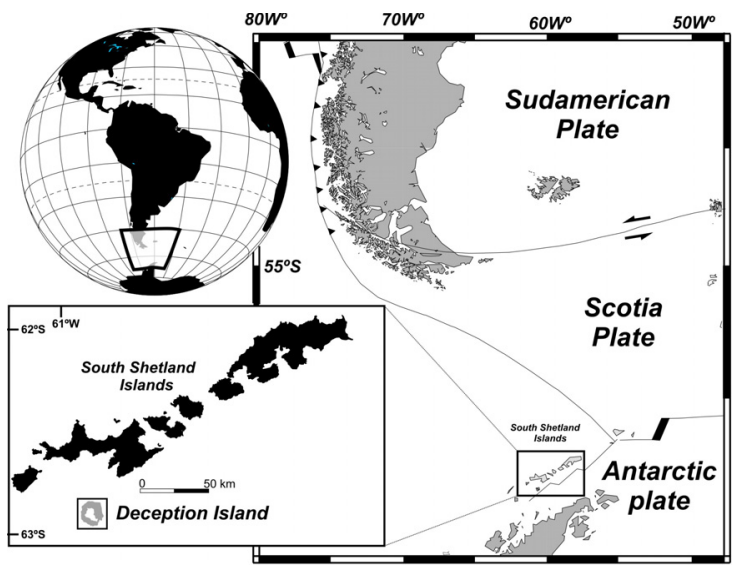

Figure 1. Geographical location of the studied area: Deception Island, Bransfield Strait.

The newly developed structural technique of fractal analysis can be applied (Pérez-López et al., 2005; PérezLópez and Paredes, 2006). Lineaments (faults, joints and dikes) form fractal sets that can be analysed in terms of stress tensors (Pérez-López et al., 2005). Caldera collapse was a major feature of Deception Island history. Port Foster is a flooded inner bay with a perimeter of $\mathrm{ca} 32 \mathrm{~km}$ and maximum depth of $350 \mathrm{~m}$. Caldera collapse results in development of ring and radial faults evidenced by fieldwork.

Bosworth et al. (2000) and Holohan et al. (2005) described several types of such faults from laboratory experiments and fieldwork. They pointed out that the shape of the caldera could be determined by the stress regime, amongst other parameters. When collapse occurs 


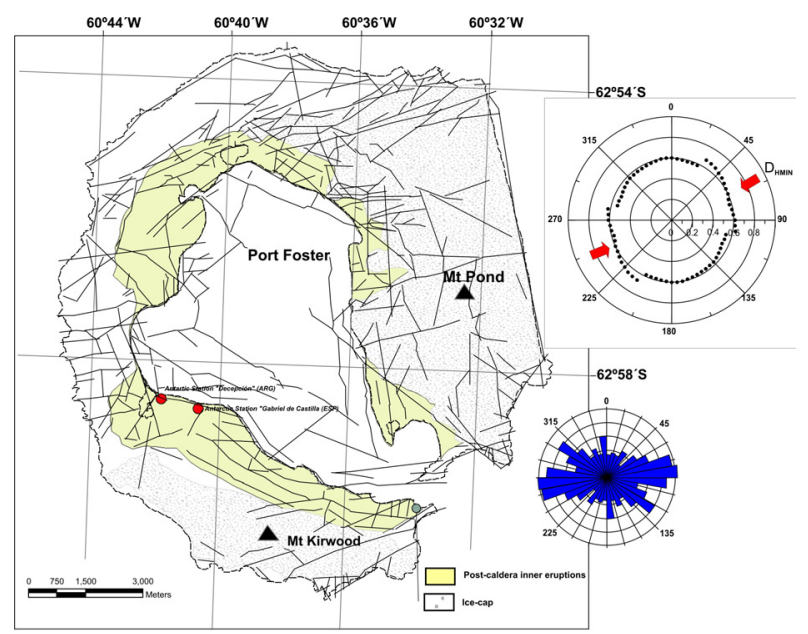

Figure 2. Left: Morpholineaments map interpreted from the DEM of 25 x 25 m pixel-size. Right: Fractal ellipse obtained from the spatial distribution of lineaments. Rose diagram represents morpholineaments frequency. See text for further explanation.

under a stress field, the resulting caldera is elliptical in plan view, with the minor axis $\left(\mathrm{e}_{\min }\right)$ parallel to $\mathrm{S}_{\text {HMAX. }}$

\section{Methodology and analysis \\ Fractal analysis}

The spatial distribution of fractures represents a fractal set (Gillespie et al., 1993). Pérez-López et al., (2005) demonstrated that this spatial distribution is related to the stress field in any particular zone. The technique proposed by these authors is rather simple. Firstly, they build a morpholineaments map from a digital elevation model (DEM). Main orientations of the lineament sets are then compared with faults, dikes and veins orientations, measured from fieldwork and boreholes. Secondly, the fractal set is obtained by using 1-D box-counting technique along a transect intersecting the filtered lineament sets. Two parameters are obtained, the fractal dimension of spatial points distribution $\left(\mathrm{D}_{0}\right)$ and the trend of the transect $(\delta)$. Plotting these parameters $\left(\mathrm{D}_{0}, \delta\right)$ in a polar graph allows determination of an ellipse, defined as the fractal ellipse of the lineaments spatial distribution. Pérez-López et al. (2005) concluded that the fractal anisotropy of fracture distribution can be measured and is a consequence of the stress field that generates the spatial fracture patterns. The minor axis of this fractal ellipse $\left(D_{\text {HмIN }}\right)$ is parallel to the maximum horizontal stress axis orientation $\left(\mathrm{S}_{\mathrm{HMAX}}\right)$.

For Deception Island, we obtained the DEM from the 1:25.000 topographic map (SGE, 2006) with $25 \times 25 \mathrm{~m}$ pixel-size. The map of lineaments shows 630 structures trending mainly ENE-WSW, with secondary sets oriented NW-SE and N-S (Fig. 2). In order to determine the fractal anisotropy, the software developed by Hart and Rudman (1997) was applied. Figure 2 (right) shows the results.
Two truncated ellipses are observed and therefore two stress fields are responsible for the interpreted pattern of lineaments (Perez-Lopez and Paredes, 2006). The most evident ellipse has a $D_{\text {HMIN }}$ trending ENE-WSW. Therefore, the $\mathrm{S}_{\text {HMAx }}$ trending is ENE-WSW. The secondary ellipse exhibits a small difference between both axes, indicating that $\mathrm{S}_{\mathrm{HMAX}}$ and $\mathrm{S}_{\mathrm{HMIN}}$ have a similar magnitude.

\section{Strain analysis}

Strain analysis determines the strain field from slip vectors obtained from fault planes in the field. Two principal axes define the strain field: the maximum (ey) and the minimum (ex) horizontal shortening. The strain field characterizes the tectonic regime of an area and indicates its' the geodynamic evolution. The strain analysis was done following the method of Reches (1987), and it allows us to establish the orientation of ey from the slip sense values obtained in each fault plane.

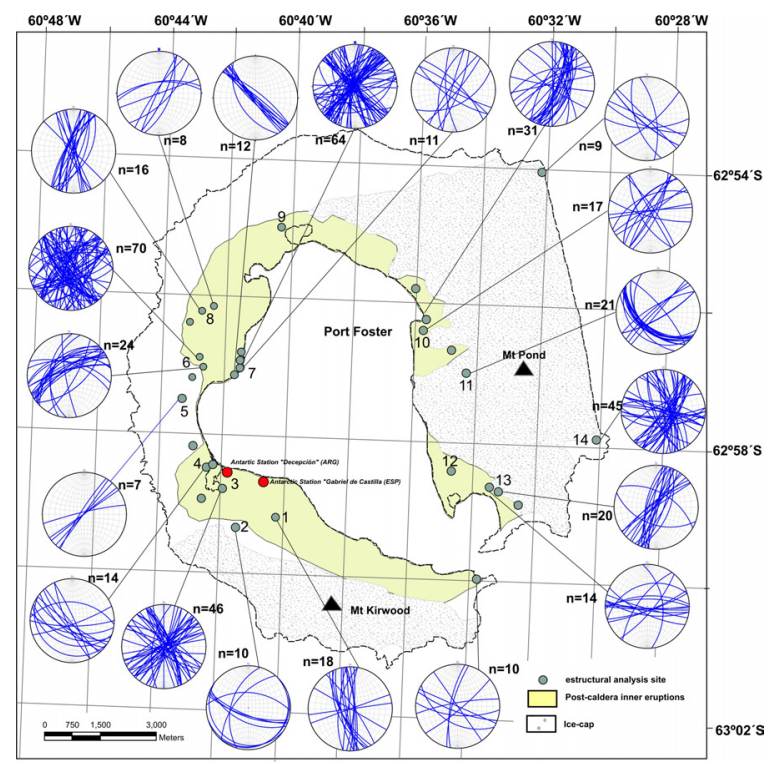

Figure 3. Stereogram plots of the fault planes measured by fieldwork.

In total, 575 structural data (faults, joints and dikes) were collected during several field campaigns (2004, 2005 and 2007) at Deception Island. From these, 457 structural fault measurements from 20 field stations were obtained (Fig. 3). 90 percent of these faults effect postcaldera, shortened, basal surge volcanic deposits with cross bedding (so-called P1 in the Geological Map by Smellie, 2002).

From this analysis, we have established two strain fields at Deception Island (Fig. 4):

1 - Extensional strain field with left-lateral component (ey NE-SW trending), characterized by oblique- normal and normal faults. The ey trend calculated above is parallel with the regional orientation of $\mathrm{S}_{\mathrm{HMAX}}$ (NE-SW) obtained by others authors (Galindo-Zaldívar et al., 1996, 


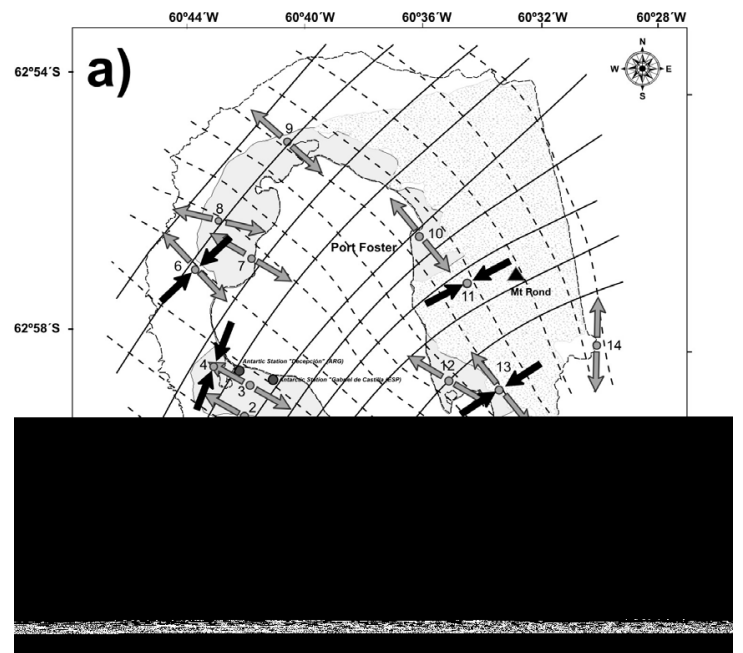

Figure 4. Strain trajectories obtained from the structural fault population: a) Primary strain field with ey NE-SW trending, and b) secondary strain field with ey NW-SE trending.

González-Casado et al., 2000 and Maestro et al., 2007). 2- Secondary uniaxial extension, probably related to the caldera collapse. In this case, the ey is oriented towards NW-SE. This field is characterized by normal faults and is orthogonal to the regional stress field defined by authors mentioned above.

No relative temporal relationships between both strains fields obtained here can be established.

\section{Caldera boundary}

Deception Island is a volcanic complex with an inner bay (Port Foster) formed by caldera collapse. The inner shoreline is irregular and elongated NW-SE. At present, the caldera boundary of the island is unknown. Postcaldera eruptions have covered and strongly modified the inner shoreline. Holohan et al. (2005) described fracture sets associated with caldera collapse. They point out that ring and radial faults control the brittle deformation related to the collapse process. The analysis of these sets and the topography allows the definition of the inner caldera boundary. However, few fault sets have been described on Deception Island (Rey et al., 1995, 2004, Fernández-Ibáñez et al., 2005; Maestro et al., 2007) and it is difficult to determine the caldera boundary. Furthermore, bathymetric analysis shows irregular baybottom topography.

Despite this, we defined the caldera boundary of Deception Island using the following features (Fig.5):

a- Vent alignment of post-caldera craters in the inner shoreline.

b- Eruptive fissures associated with post-caldera deposits.

c- Major recent faults (Rey et al., 1995, Smellie, 2002).

d- Minor recent faults.

e- Post-caldera volcanic deposits (Smellie et al., 2000).

f- Active alluvial fans (Quickbird high-resolution satellite imagery).

The obtained caldera boundary shows an elliptical shape with the major axis $\left(\mathrm{e}_{\max }\right)$ trending NW-SE and the minor axis trending NE-SW. According to Holohan et al. (2005) and Bosworth et al. (2000), this shape is consistent with a caldera collapse developed in a stress field with $\mathrm{S}_{\text {HMAX }}$ NE-SW trending.

Bosworth et al. (2000) interpreted that the caldera elongation reflects a similar shape in the underlying magma chamber. This implies a mechanical response to the presence of non-hydrostatic stresses in the adjacent country rock. They interpreted the elliptical shape of calderas as a breakout process where the presence of preexisting oriented structures determines the ellipsoidal growing of the magma chamber.

\section{Discussion and conclusions}

The main stress field defined from the fractal analysis at Deception Island is similar to that obtained by others

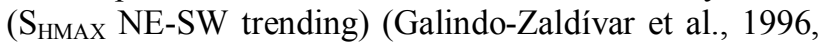
González-Casado et al., 2000 and Maestro et al., 2007).

The strain analysis performed here reveals two active fields. A first strain tensor defined by ey with NE-SW trending. We assume this strain field as a regional field due to the maximum shortening direction is parallel to the regional $\mathrm{S}_{\text {HMAX }}$ trending (NE-SW, Galindo-Zaldívar et al., 1996, González-Casado et al., 2000 and Maestro et al., 2007). The secondary strain tensor is defined by ey with NW-SE trending. We assume that this strain field has a local character. Only six structural stations show this tensor, whilst the main strain field appears in all structural stations (see Fig. 4).

Both strain fields defined here have orthogonal orientations. Assuming these strain fields could be coeval, ey and ex could switch through time and thus generate the roughly orthogonal shortening and extension directions. Vent alignment, active structures and post-caldera inner deposits, show that the caldera boundary is elliptical in plan view, with the minor axis $\left(\mathrm{e}_{\min }\right)$ trending NE-SW, compatible with the orientation of $\mathrm{S}_{\mathrm{HMAX}}(\mathrm{NE}-\mathrm{SW})$ 


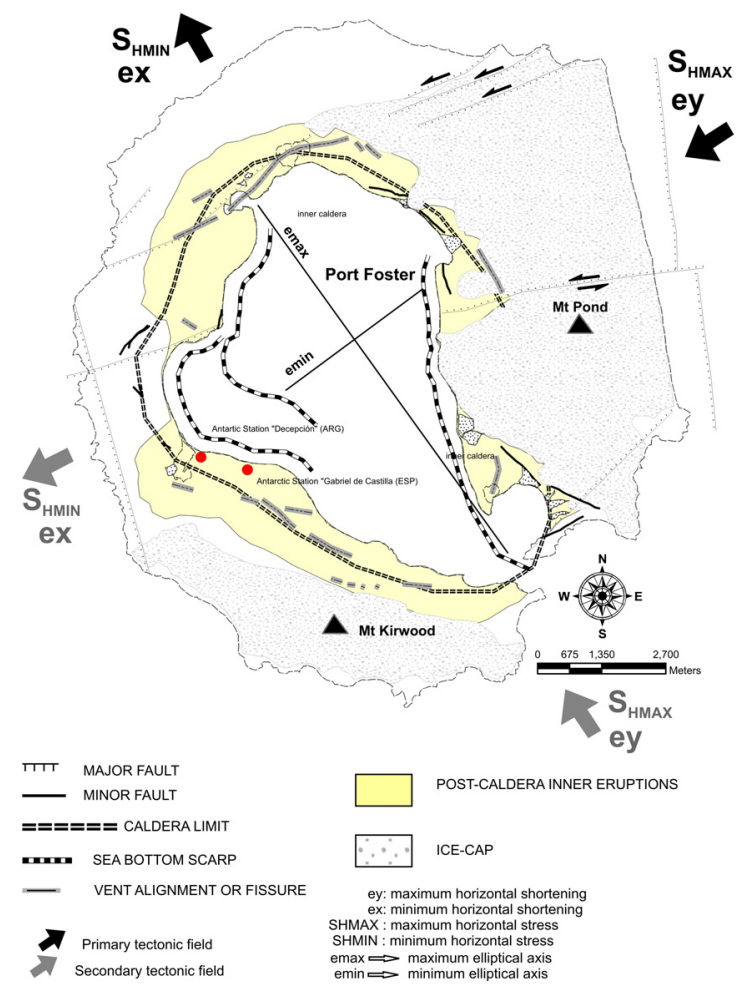

Figure 5. Caldera boundary of Deception Island. Stress and strain fields obtained in this work. When ey and $\mathrm{S}_{\mathrm{HMAX}}$ are parallel, only one arrow is indicated.

obtained from the fractal analysis. This can be interpreted as resulting from either the regional tectonic field (Galindo-Zaldívar et al., 1996, González-Casado et al., 2000, Maestro et al., 2007), or the breakout model of preexiting NW-SE striking structures.

We conclude that Deception Island evolved through collapse of a huge volcanic edifice under a regional stress regime with $\mathrm{S}_{\text {HмAX }}$ oriented NE-SW. This regional stress at Deception Island produced movement on obliquenormal and normal faults, with NNE-SSW to ENE-WSW trending. This could occur due to the interaction between the regional tectonic regime of the Bransfield Strait and the dynamics of the magma chamber within the island.

Acknowledgments. Thanks are given to A. K. Cooper and C. R. Raymond as co-editors of this book. We appreciate the suggestions and remarks of Keith H. James and Tim Paulsen. This work has been supported by the inter-ministerial Spanish Science Project FALLADEC, CGL2005-24148-E/ANT. We would give a special mention to the Spanish Army of the Antarctic Station Gabriel de Castilla and the Argentinean Antarctic Station Decepción.

\section{References}

Bosworth, W., Burke, K., Strecker, M. (2000), Magma chamber elongation as an indicator of intraplate stress field orientation: "borehole breakout mechanism" and examples from the Late Pleistocene to Recent Kenya Rift Valley. In: Stress, Strain and Structure. A volume in honour of W.D. Means. Eds.: M.W. Jessell and J.L. Urai. Vol 2, Journal of the Virtual Explorer.

Fernández-Ibáñez, F., R. Pérez-López, J.J. Martínez-Díaz, C. Paredes, J.L. Giner-Robles, A. T. Caselli and J. M. Ibáñez (2005), Costa Recta beach, Deception Island, West Antarctica: a retreated scarp of a submarine fault?, Ant. Sci., 17(3), 418-426.

Galindo-Zaldívar J., A. Jabaloy, A. Maldonado and C. Sanz de Galdeano (1996), Continental fragmentation along the South Scotia Ridge transcurrent plate boundary (NE Antarctic Peninsula), Tectonophysics, 259, 275-301.

Gillespie, P.A., C.B. Howard, J.J. Walsh, J. Watterson (1993), Measurement and characterisation of spatial distribution of fractures, Tectonophysics, 226, 113-141.

Gonzalez-Casado J.M., J. López-Martínez, J.L. Giner, J.J. Durán, P. Gumiel (1999), Análisis de la microfracturación en la Isla Decepción. Antártida Occidental, Geogaceta, 26, 31-34.

González-Casado, J.M., J.L. Giner-Robles \& J. López-Martínez (2000), Bransfield Basin, Antarctic Peninsula: not a normal backarc basin, Geology, 28, 1043-1046.

Hart, D. and Rudman, A.J., 1997. Least-square fit of an ellipse to anisotropic polar data: application to azimuthally resistivity surveys in karst regions. Computers \& Geoscience, 23, 189-194.

Holohan, E.P., V.R. Troll, T.R. Walter, S. Münn, S. McDonnell, Z.K. Shipton (2005), Elliptical calderas in active tectonic settings: an experimental approach, J. Vol. Geothermal Res., 144, 119-136.

Maestro, A., L. Somoza, A. Barnolas, J. Rey, J. Martínez-Frías and J. López-Martínez, (2007), Active tectonics, fault patterns and stress field of Deception Island: A response to oblique convergence between the Pacific and Antarctic Plates, J. South Am. Sci. 23, 253-268.

Paredes, C., R. Perez-Lopez, J. L Giner-Robles, R. de la Vega, A. Garcia-Garcia, and P. Gumiel (2006), Distribucion espacial y zonificacion tectonica de los morfolineamentos en la Isla Decepcion (Shetland del Sur, Antartida), Geogaceta, 39, 75-78.

Pérez-López , R. and C. Paredes (2006), On measuring the fractal anisotropy of 2-D geometrical sets: Application to the spatial distribution of fractures, Geoderma, 134, 402-414.

Pérez-López, R., C. Paredes, A. Muñoz-Martín (2005), Relationship between the fractal dimension anisotropy of the spatial faults distribution and the paleostress fields on a Variscan granitic massif (Central Spain): the F-parameter, J. Struc. Geol., 27, 663-677.

Pérez-López, R., Giner-Robles, J.L., Paredes, C., Martínez-Díaz, J.J., Rodríguez-Pascua, M.A., de la Vega, R., González-Casado, J. M. (2006), Caracterización de la deformación en Isla Decepción mediante el estudio fractal de morfoestructuras. Libro de resumenes, VII Simposio de Estudios Polares,: 264-267. Granada.

Reches, Z. (1987), Determination of the tectonic stress from slip along faults that obey the Coulomb yield condition, Tectonics, 7, 849-861.

Rey J., L. Somoza, J. Martínez-Frías (1995), Tectonic, volcanic and hidrotermal event sequence on Deception Island (Antarctica), Geo. Mar. Lett., 15, 1-8.

SGE, 2006. Servicio Geográfico Español Ejército de Tierra. Hoja Topográfica: Isla Decepción. Escala 1:25.000.

Smellie J. L., (2002), Geology, In: Smellie, J.L. López-Martínez J. et al. (Eds.), Geology and geomorphology of Deception Island, 78pp. GEOMAP Series Sheets 6-A 6-B, 1:25.000. Cambridge, British Antarctic Survey, pp. 11-30. 